\title{
Internal Determinants of Commercial Bank Profitability In Indonesia
}

\author{
Umi Widyastuti
}

Dedi Purwana E.S

\author{
Sri Zulaihati
}

Doi:10.5901/mjss.2017.v8n3p219

Faculty of Economics, Universitas Negeri Jakarta, Jakarta 13220, Indonesia

\begin{abstract}
Internal determinants of bank profitability can be defined as those factors that are influenced by the bank's management decisions and policy objectives. This paper is aimed to examine the internal factors that impact on commercial banks profitability in Indonesia. The factors reviewed in the model namely capital adequacy, credit risk (non-performing loan), liquidity (loans to deposit ratio), net interest margin and operating efficiency (operating expenses to operating income ratio). Using purposive sampling method, the analysis used thirty three commercial banks, with 168 observations for the period 2010 to 2015. Based on the Chow-test, the common effect model was preferred. The model is estimated using Ordinary Least Squares method. The results revealed that two hypotheses were not be accepted. There are no significant effects of capital adequacy and credit risk on profitability, but the model explains that there are significant effects of all explanatory variables toward commercial bank profitability. However, other important internal determinants of bank profitability still have not included in the model of this paper.
\end{abstract}

Keywords: capital adequacy, non-performing loan, net interest margin, loan to deposit ratio, operating efficiency, profitability

\section{Introduction}

As one of crucial financial institutions, the bank was contributing to the economic development. An efficient banking sector contributes positively to economic development by promoting capital accumulation through supply of credit (Onuonga, 2014). It has the role as a financial intermediary that serves people with the alternatives of investment and financing products. Therefore, in performing its activities to facilitate between surplus units and deficit units, trust is solely its major capital. So, the financial performance of banks has to be considered in maintaining the public trust. The performance of banks can be measured using the bank's profitability. According to Flamini, Schumacher, and McDonald (2009), profitability is one of the important indicators in the banking industry that represented by Return on Assets (ROA). ROA indicates the effectiveness of the bank in generating profit using its assets.

Many studies of determinant of bank profitability have been undertaken, including some previous researches by Hester and Zoellner (1966), Short (1979); Bourke (1989); Molyneux and Thornton (1992), Steinherr and Huveneers (1994). While some studies explain that the determinant of bank profitability involves both external and internal factors (Bourke, 1989; Staikouras \& Wood, 2011). The external factors have been analysed to investigate the bank profitability including interest rate (Adem Anbar, 2011; Wibowo \& Saichu, 2013), concentration (Molyneux \& Thornton, 1992), inflation (Wibowo \& Saichu, 2013), economic growth (Sufian \& Habibullah, 2009). Meanwhile, the internal determinants that impact the bank profitability including size (Adem Anbar, 2011; Flamini et al., 2009), diversification, ownership (Flamini et al., 2009; Onuonga, 2014) and also capital strength, operations expenses (Onuonga, 2014), capital and loan to assets ratio (Hassan \& Bashir, 2003), credit risk, liquidity (Sufian \& Habibullah, 2009). However, some empirical studies have shown a different result when it is applied in many countries and analysed in a different period. So, the aim of this study is to investigate the internal determinants of commercial banks profitability in Indonesia within the period 2010-2015.

\section{Review of Literatures}

According to Staikouras and Wood (2011), internal determinants of bank profitability can be defined as those factors that are influenced by the bank's management decisions and policy objectives. The internal management basically reflects on the difference of bank management policies and decisions in obtaining and using of funds; including capital and loan to deposit ratio managements, and expenses managements (Guru, Staunton, \& Balashanmugam, 2002). This study 
explored the internal determinant namely capital adequacy, non-performing loan, loan to deposit ratio, operating efficiency and net interest margin.

To be able to perform their function, banks should have enough capital and allocate their funds on the assets including credit properly. The requirements of minimum capital adequacy which is needed by commercial banks in Indonesia have been determined in a rule by the Central Bank. The Central Bank of Indonesia (2013) has been set a minimum capital fulfilment which is represented by Capital Adequacy Ratio (CAR). It should reach the level at no less than $8 \%$. This was confirmed by Sabir. M, Ali, and Habbe (2012), Lestari (2014) that the CAR has shown a positive impact on the profitability of banks. Instead, Purwoko and Sudiyatno (2013); Prasanjaya and Ramantha (2013), Wibowo and Saichu (2013) explains that the CAR did not have an impact on profitability.

The banking industry has become an industry that is facing various risks, since it involves the decision about funding and lending. In carrying out the intermediation function, banks manage the funds which are collected from the community and invest it in various forms of instruments, such as loans, the purchase of securities and others. Banks have role to attract funds from saving deposit, demand deposit and time deposit. In allocating their funds, they face a credit risk. It is measured by non-performing loans (NPL) or problem loans. NPL affects directly to the bank's performance, especially in performing asset quality. The higher NPL will reduce bank income (revenue). Purwoko and Sudiyatno (2013), Eng (2013), found that the NPL has a negative effect on ROA. Otherwise, Aini (2013) stated that NPL has no significant effect on profit changes.

Another risk in the banking industry is the market risk. Market risk can be defined as the risk that arising from movements in market variables (adverse movement) of the portfolio held by banks that could result in losses to the bank. The market variables consist of interest rate and exchange rate. In this paper, Net Interest Margin (NIM) is used as proxies of market risk. It defines as the spread between interest income and interest expense. Therefore NIM has an influence on the bank's financial performance. In line with this, Purwoko and Sudiyatno (2013) find a positive influence between NIM towards profitability.

Meanwhile, loan to deposit ratio (LDR) is the ratio that describes how much allocation of funds in term of credit, comparing to a number of funds which is obtained from saving. Hassan and Bashir (2003), Prasanjaya and Ramantha (2013), Sufian and Habibullah (2009), Margaretha and Zai (2013) showed that the increase in LDR will increase in profits of banks. While Sabir. M et al. (2012) explained that LDR has a negative effect to profitability. Even, Purwoko and Sudiyatno (2013); Hutagalung, Djumahir, and Kusumaratnawati (2013) found that LDR has no effect on profitability. Aini (2013) also found that LDR has no significant effect on profit changes.

Operating efficiency is also one of the factors that must be controlled to see whether the bank operates efficiently or not. It is usually measured by operating expenses to operating income ratio. This ratio shows the amount of operating income that is spent in a period comparing with the income which is earned from operating activities. Therefore, Lestari (2014) explains that operating efficiency affects to the bank's profitability. While, Purwoko and Sudiyatno (2013) concluded that operating efficiency has impacted to the banks performance negatively. It shows that the larger rate on ratio of total operating expenses to operating income will decrease profitability. While Sabir. M et al. (2012) found that operating efficiency has no significant effect on profitability.

Here are five alternative hypotheses to be tested in this paper, as follow:

$\mathrm{H} 1$ - There is significant impact of capital adequacy ratio on profitability.

$\mathrm{H} 2$ - There is significant impact of non-performing loan on profitability.

$\mathrm{H} 3$ - There is significant impact of net interest margin on profitability.

$\mathrm{H} 4$ - There is significant impact of loan to deposit ratio on profitability.

$\mathrm{H} 5$ - There is significant impact of operating efficiency on profitability.

\section{Research Methodology}

Specific criteria to take the research sample are explained as follows:

a. Commercial bank in Indonesia based on directory of the Central Bank of Indonesia.

b. Commercial bank which routinely provides complete data and publish financial statements during the period 2010 - 2015.

Samples were taken using purposive sampling technique. Based on the criteria above, the numbers of samples which have fulfilled the criteria are 33 banks. The balanced panel data used in this research is secondary data from the financial statements. It is obtained from the directory of the Central Bank of Indonesia for the period 2010 to 2015. Therefore, data was analysed using Ordinary Least Square methods with 168 observations. The hypotheses have been tested using t-test based on 0.05 significant levels. 


\section{Empirical Findings}

This section provides the empirical results of this paper, as shown at Table 1. Based on the Chow-test, the common effect model was preferred. The model is estimated using Ordinary Least Squares method. The findings will be arranged by explaining the effect of each internal determinant factor on bank profitability, as follows:

Table 1. Ordinary Least Square

\begin{tabular}{|l|c|c|c|}
\hline & Coefficient & t-stat & Prob value \\
\hline Constant & 6.927106 & 11.66287 & 0.0000 \\
\hline CAR & 0.003436 & 0.252600 & 0.8008 \\
\hline NPL & -0.073217 & -1.213319 & 0.2265 \\
\hline NIM & 0.227497 & 6.614981 & 0.0000 \\
\hline LDR & -0.010613 & -2.922487 & 0.0039 \\
\hline Operating efficiency & -0.066221 & -14.16802 & 0.0000 \\
\hline R $^{2}$ & \multicolumn{3}{|c|}{0.6553} \\
\hline Prob. (F statistics) & \multicolumn{3}{|l}{} \\
\hline
\end{tabular}

\subsection{The Effects Of Capital Adequacy On Profitability}

The capital is a major component which drives the business development. CAR is a ratio which represents the capital adequacy of the bank. In general, the capital of the commercial bank in Indonesia on the period of observation is quite good. It is supported with an average value of $16,82 \%$. According to the Central Bank of Indonesia, the minimum requirement of CAR for commercial bank is no less than $8 \%$.

Based on data analysis, the coefficient of CAR in this model is 0.0034 and the probability value of $t$ test on CAR is 0.8008. Therefore $\mathrm{H} 1$ is rejected. Although some previous studies explain that the larger CAR will lead to the higher bank profitability, but this study reveals that CAR was insignificant to influence bank profitability. Because they concern on their sustainability, banks are consistently applying prudential principles in investing their funds. Ideally, the capital should not invest only on credit, but it should be allocated in financial instrument or tangible assets, both in the long term or short term period.

The result of this study is in line with Hutagalung et al. (2013) research. Her study explains that banks rely on loans as the main source of interest income. It does not mean that they do not necessary to optimize their funds through investing in productive asset. Banks should offer various products and services beyond credit in order to increase feebased income. It is also supported by previous studies including Purwoko and Sudiyatno (2013); Prasanjaya and Ramantha (2013), Wibowo and Saichu (2013). Their findings state that CAR has no significant effect on profitability.

\subsection{The Effect of NPL on profitability}

Loans will generate interest income that give a contribution on bank profitability, but it will affect bank liquidity if there are so many problem loans. NPL is the ratio that indicates the ability of management to control non-performing loans. Supported by the data, the average value of NPL is $1.43 \%$. It is less than the minimum requirement of the Central Bank of Indonesia. This study shown that the coefficient of regression for NPL is 0.0732 . Because $p$-value is higher than 0.05 of significance level, it can be concluded that the second hypotheses $(\mathrm{H} 2)$ is rejected. It indicates that there is no significant effect of NPL on profitability. Aini (2013) also found that there is no significant effect of NPL on profit changes. Otherwise, Purwoko and Sudiyatno (2013), Eng (2013), Margaretha and Zai (2013), Hutagalung et al. (2013); has shown the opposite result. Both of them revealed that there is a negative significant effect of NPL on profitability.

In general, commercial bank in Indonesia has applied the precautionary principle in lending decision. The regulation of the Central Bank of Indonesia requires NPL not exceed 5\%, could be met properly. The bank's management has done more rigorous selection of the customers who will get some loan. If the credit quality can be improved, it will reduce problem loans and increase the bank profitability.

Banks will tend to have a high NPL, if the numbers of non-performing loans increase. If the bank has a high NPL, it can increase their operating costs, both allowance productive assets and other costs. In other words, the higher NPL will cause some difficulties in liquidity and directly influence the bank performance. 


\subsection{The Effect of NIM on profitability}

NIM reflects the ability of the banks management in managing their productive assets to generate net interest income. Banks face the smaller possibility in difficulties of liquidity when it has a positive spread in net interest. It describes the condition where the banks get more interest income than pay interest expense. The larger NIM represents the better bank performance. Based on data analysis, $p$-value of NIM is 0.000 which is smaller than 0.05 of significance level. Thus the third hypothesis $(\mathrm{H} 3)$ is accepted, so it can be stated that there is a positive significant impact of NIM on profitability. It has the coefficient of regression 0.2274 .

In many research, NIM is one of the proxies of bank performance (Flamini et al., 2009; Naceur, 2003). However, according to the Central Bank of Indonesia, interest rate represents market risk. In this case, the market risk describes every change in interest rate that will affect earning of the bank. The interest rates consist of saving, investment and credit. Net interest is obtained by measuring the difference between interest incomes with interest expenses. The positive value of net interest contributes to the income and also affects the bank profitability. If the difference between loans to saving interest rate is low, NIM will tend to be low. It represents that the market risk is high, and vice versa. The interest margin can shows negative amount. It will occur when interest rates for lending is lower than deposit rates. Based on secondary data during period 2010-2015, the average value of NIM for commercial bank in Indonesia is 5.39\%. This indicates that the interest rates on loans (lending) is still higher than the interest rate for borrowing or funding.

\subsection{The Effect of LDR on profitability}

Refers to the results on table 1 , the fourth hypotheses $(\mathrm{H} 4)$ was accepted. The probability value of LDR is 0.02 , which is less than 0.05 of significance level. It shows that there is a negative significant influence of LDR on profitability. The coefficient of LDR is -0.0106 . It explains that the higher LDR will represent the lower profitability. LDR reflects the proportion of bank loan to deposit ratio. LDR measures the bank ability to meet the repayment of deposits that have been on maturity and to fulfil credit applications which is proposed by the debtor without delay. This ratio reflects bank liquidity. High LDR show more risky conditions because the fund from deposit have been allocated in more of credit, conversely the lower LDR indicate ineffective banks in lending decisions.

Based on the data during the period of $2010-2015$, this study shows the average value of NPL is $85.82 \%$. While comparing to the regulation from the Central Bank of Indonesia, LDR was determined in between $78 \%$ to $100 \%$. In general, all commercial bank in Indonesia could be categorized as healthy bank. It also gives an explanation that commercial bank in Indonesia has been effectively allocating the third party funds in term of loans to the public. Effectiveness in performing the intermediary function will affect the efficiency of the bank. Because operating income is gained mostly from the interest income for lending.

\subsection{The effect of operating efficiency on profitability}

The result of this study reveals that the fifth hypotheses $(\mathrm{H} 5)$ is accepted. There is a negative significant impact of operating efficiency on profitability. The coefficient of regression is -0.0662 . Operating expenses to operating income ratio is the ratio that measures the ability of management to control operating activities. It represents bank efficiency. As an intermediary institution, banks have the main activity in collecting and lending funds to the public. The consequences of its activity, bank has to spend much expenditure. It is dominated by interest expense. On the other hands, bank's operating income mostly generate from interest income. High ratio on operating efficiency indicates that the bank has not been able to utilize the resources they have. Bank has not been able to carry out its operations efficiently, so that it will decrease the profitability. The smaller of ratio of operating efficiency indicates an increasing in bank efficiency, so the opportunity to get more profits will be higher.

The average value of operating efficiency ratio on sample is $84.99 \%$. In general, this value shown that the commercial bank in Indonesia has met the requirement which is determined by the Central Bank of Indonesia. Banks have to fulfil the rate of operating efficiency ratio no less than 100\%. Commercial bank in Indonesia should be able to optimize its operations in order to achieve efficiency levels. If commercial bank operates efficiently, the profitability tends to increase.

Based on the results on table 1, this paper reports that the model was significantly influence of bank profitability. All of the explanatory variables have an impact on profitability. Profitability of commercial bank in Indonesia are explained by capital adequacy, credit risk (non-performing loan), net interest margin, loan to deposit ratio and operating expense to operating income ratio in amount of $65,53 \%$. 


\section{Conclusion}

This paper has explored the impact of internal bank's characteristics on profitability; including capital adequacy, nonperforming loan, net interest margin, loan to deposit ratio and operating efficiency for the period of 2010-2015. Based on data analysis, this paper has shown that net interest margin, loan to deposit ratio and operating efficiency has significant impact on profitability. On the other hand, two hypotheses are not accepted. Capital adequacy and non-performing loan (credit risk) has no significant impact on profitability. But the model explains that there are significant effects of explanatory variables toward bank profitability. However, the other important internal determinants of bank profitability still have not included yet in the model of this study. This research implies for the future researches that it should explore the impact of some internal determinants on profitability using another type of bank such as Islamic bank.

\section{References}

Adem Anbar, D. A. (2011). Bank specific and macroeconomic determinants of commercial Bank profitability: empirical evidence from Turkey. Business and economics research journal, 2(2), 139-152.

Aini, N. (2013). Pengaruh CAR, NIM, LDR, NPL, BOPO, dan kualitas aktiva produktif terhadap perubahan laba (Studi Empiris Pada Perusahaan Perbankan yang terdaftar di BEI) Tahun 2009-2011. Dinamika Akuntansi Keuangan dan Perbankan, 2(1), 14-25.

Bourke, P. (1989). Concentration and other determinants of bank profitability in Europe, North America and Australia. Journal of Banking and Finanace, 13(1), 65-79.

Eng, T. S. (2013). Pengaruh NIM, BOPO, LDR, NPL \& CAR terhadap ROA bank internasional dan bank nasional go public periode 2007-2011. Jurnal dinamika manajemen, 1(3), 153-167.

Flamini, V., Schumacher, M. L., \& McDonald, M. C. A. (2009). The determinants of commercial bank profitability in Sub-Saharan Africa: International Monetary Fund.

Guru, B. K., Staunton, J., \& Balashanmugam, B. (2002). Determinants of commercial bank profitability in Malaysia. Journal of Money, Credit, and Banking, 17, 69-82.

Hassan, M. K., \& Bashir, A.-H. M. (2003). Determinants of Islamic banking profitability. Paper presented at the 10th ERF annual conference, Morocco.

Hester, D. D., \& Zoellner, J. F. (1966). The relation between bank portfolios and earnings: An econometric analysis. The Review of Economics and Statistics, 372-386.

Hutagalung, E. N., Djumahir, \& Kusumaratnawati. (2013). Analisa rasio keuangan terhadap bank umum di Indonesia. Jurnal Aplikasi Manajemen, 11(1), 122-130.

Lestari, D. (2014). Analisis pengaruh rasio CAR, BOPO, dan LDR terhadap kinerja keuangan perbankan yang terdaftar di Bursa Efek Indonesia Tahun 2008-2012. Paper presented at the Seminar Nasional dan Call for Paper Syariah Paper 2014

Margaretha, F., \& Zai, M. P. (2013). Faktor-faktor yang memepengaruhi kinerja keuangan perbankan Indonesia. Jurnal bisnis dan akuntansi, 15(2), 133-141.

Molyneux, P., \& Thornton, J. (1992). Determinants of European bank profitability: A note. Journal of banking \& Finance, 16(6), 1173-1178.

Naceur, S. B. (2003). The determinants of the Tunisian banking industry profitability: Panel Evidence.

Onuonga, S. M. (2014). The Analysis of Profitability of Kenyas Top Six Commercial Banks: Internal Factor Analysis. American International Journal of Social Science, 3(5), 94-103.

Prasanjaya, A. A. Y., \& Ramantha, I. W. (2013). Analisis pengaruh rasio CAR, BOPO, LDR dan ukuran perusahaan terhadap profitabilitas bank yang terdaftar di BEI. E-Jurnal Akuntansi Universitas Udayana, 4(1), 230-245.

Purwoko, D., \& Sudiyatno, B. (2013). Faktor-Faktor Yang Mempengaruhi Kinerja Bank (Studi Empirik Pada Industri Perbankan Di Bursa Efek Indonesia). Jurnal Bisnis dan Ekonomi, 20(1).

Sabir. M, M., Ali, M., \& Habbe, A. H. (2012). The Influence of Ratio Financial Results For Bank of Islamic Banks and Conventional Banks in Indonesia. Jurnal Analisis, 1(1), 79-86.

Short, B. K. (1979). The relation between commercial bank profit rates and banking concentration in Canada, Western Europe, and Japan. Journal of banking \& Finance, 3(3), 209-219.

Staikouras, C. K., \& Wood, G. E. (2011). The determinants of European bank profitability. International Business \& Economics Research Journal (IBER), 3(6), 57-68.

Steinherr, A., \& Huveneers, C. (1994). On the performance of differently regulated financial institutions: Some empirical evidence. Journal of banking \& Finance, 18(2), 271-306.

Sufian, F., \& Habibullah, M. S. (2009). Bank specific and macroeconomic determinants of bank profitability: Empirical evidence from the China banking sector. Frontiers of Economics in China, 4(2), 274-291.

Wibowo, E. S., \& Saichu, M. (2013). Analisis pengaruh suku bunga, inflasi, CAR, BOPO, NPF terhadap profitabilitas bank syariah Diponegoro journal of accounting, 2(2), 1-10. 
ISSN 2039-2117 (online)

ISSN 2039-9340 (print)
Mediterranean Journal of Social Sciences MCSER Publishing, Rome-Italy
Vol 8 No 3

May 2017 